Winter 2005

\title{
The Language of Higher Education Assessment: Legislative Concerns in a Global Context
}

Bonnie Urciuoli

Hamilton College

Follow this and additional works at: https://www.repository.law.indiana.edu/ijgls

Part of the Education Law Commons, International Law Commons, and the Legislation Commons

\section{Recommended Citation}

Urciuoli, Bonnie (2005) "The Language of Higher Education Assessment: Legislative Concerns in a Global Context," Indiana Journal of Global Legal Studies: Vol. 12 : Iss. 1 , Article 6.

Available at: https://www.repository.law.indiana.edu/ijgls/vol12/iss1/6

This Symposium is brought to you for free and open access by the Law School Journals at Digital Repository @ Maurer Law. It has been accepted for inclusion in Indiana Journal of Global Legal Studies by an authorized editor of Digital Repository @ Maurer Law. For more information, please contact rvaughan@indiana.edu.

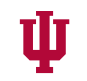

JEROME HALL LAW LIBRARY

INDIANA UNIVERSITY

Maurer School of Law
Blooming ton 


\title{
The Language of Higher Education Assessment: Legislative Concerns in a Global Context
}

\author{
Bonnie URCIUOLI*
}

\section{INTRODUCTION}

In recent years, state and federal legislatures have taken increasingly outspoken stands as guardians of the public interest regarding the costs and benefits of higher education, particularly state-funded higher education. In the 1980s, several states passed legislation requiring educational outcomes assessment for state-funded colleges and universities. Very recently, federal legislators have, while in the process of reauthorizing the Higher Education Act, begun asking for assessment regulation in all higher education, public and private. Assessment issues are not new. The search for means to measure educational outcomes emerged around 1900 with the development of educational foundations and the movement to accredit higher education institutions. This movement was motivated by a concern for commensurateness, or lack thereof, among the structurally various institutions of higher education of the late nineteenth century. In contrast, current calls for assessment are motivated by concerns for the spiraling cost of education. Nevertheless, throughout the history of U.S. higher education, the question underlying all concerns for assessment is: "What is the outcome of that education supposed to be?"

While most academics have never found any simple answers to this question, the corporate and government voices initiating these calls for assessment have tended for the past century to see higher education in terms of workforce preparation. Since 1980 or so, a globalized rhetoric of skills and work force preparedness has emerged with which U.S. discourses of education, skills, and work have become tightly coherent. In effect, this has become the new global "common sense" rhetoric of work force preparedness. Moreover, this globalized neoliberal discourse has often taken place in conservative social and political

* Department of Anthropology, Hamilton College; Ph.D. in Anthropology and Linguistics (joint program), University of Chicago, 1984. This article was originally delivered as a paper at the Twelfth Annual Symposium of the Indiana Journal of Global Legal Studies, "Globalization and Education," April 2004, Indiana University School of Law-Bloomington. My thanks to Susan Mason and to Shauna Sweet for their advice and insight. 
contexts, giving it not only the aura of common sense but of moral correctness as well. In this discourse, the central point of educational assessment is the assessment of skills that have a workplace payoff, skills having become a general term for practices or forms of knowledge that fit a worker into a job. Education as a process of inculcating skills is ideally cast as a life-long investment in human capital. Such rhetoric of education and continual skill improvement deflects attention from the structural changes of late capitalism. This rhetoric assigns responsibility for job finding and retention onto the workforce itself and onto the higher education system, which is now tasked with workforce training. In such a climate, legislative concerns with educational "value for money" appear immune to challenge and U.S. educators comply readily with legislative requests for accountability. No one examines the terms of this new "common sense"; nor, of course, are educational institutions in any position to not comply. No one asks if education has "outcomes" in the ways that private enterprises do or why private enterprise is supposed to be a model for education.

This paper proposes that the legislative calls for assessment are an assertion of control over higher education's opacity to and independence from the market logic. Market logic has attained a sort of unquestioned moral authority among political conservatives in the United States (and elsewhere) and among neoliberal market interests globally. This is reflected in the unquestioned reification of knowledge and practices as assessable skill sets. Of particular interest here is the fact that such accountability is now proposed as a way to protect the public interest. To examine these connections, I lay out the following elements: a brief sketch of key moments in higher education assessment; the function of education vis-à-vis the United States and global workforce; the rhetoric of skills accounting; contrasting perspective on skills assessment; and legislative pressures reinforcing the "common sense" of education as skills-inculcation in a globalized economy.

\section{The Call for Education Assessment: A Brief Sketch}

Higher education developed piecemeal over at least a century from multiple sources: small religious institutions, normal schools, mechanical and agricultural schools, state colleges and universities established as land grant institutions by the 1862 Morrill Act, technical and engineering schools, and research institu- 
tions established in the pattern of the German university. ${ }^{1}$ In his discussion of the contemporary corporatized university, Eric Gould points out that there has never been a "sustaining idea of what university undergraduate education consists of." Students have always gone to college for a wide variety of reasons, including social legitimation and diploma credentials. However, the idea that higher education should have specific outcomes dates from the point in university history, about a century ago, when corporate leaders appeared in critical numbers on boards of trustees and when educational foundations emerged, which combined university administrators, business connections, and engineering and technical expertise. ${ }^{3}$ With the emergence of foundation resources came the impetus to organize and standardize higher education into a typology of institutions whose outputs could be comparatively evaluated. ${ }^{4}$ There was considerable interest in the possibility of applying efficiency principles based on 1900 era business models to educational institutions. ${ }^{5}$ The first major comparative assessment of higher education institutions, covering Wisconsin, Columbia, Harvard, MIT, Toronto, Princeton, Haverford, and Williams, and initiated at the request of MIT President and first president of the Carnegie Foundation ${ }^{6}$ Henry Pritchett, was published in 1910 by Morris Cooke, a protégé of F.W. Taylor. ${ }^{7}$ Cooke concluded that, while corporate hierarchy models per se could not apply to the diffuse faculty-administrative structures of colleges and universities, there were applicable principles for commensurable assessment, based on the "student-hour" as the unit on which to calculate cost and efficiency. ${ }^{8}$ This was also the first survey to cast faculty as mental workers whose production

1. See generally Laurence R. Veysey, The Emergence of the American University (1965) (describing various institutional sources of American higher education); CLYDE W. BARrow, UNIversities and the Capitalist State: Corporate Liberalism and the Reconstruction of AmeriCan Higher Education 1894-1928 (1990) (discussing the precursor institutions of modern American higher education).

2. Eric Gould, The University in a Corporate Culture 6 (2003).

3. BARrow, supra note 1 , at $65-94$.

4. See generally id. at 64-75 (discussing the influence of foundations on the development of assessment models for higher education institutions).

5. See generally id. at 65-94 (discussing the development of ideas for the application of business models to educational institutions).

6. Id. at 65 .

7. Morris Llewellyn Cooke, Academic and Industrial Efficiency: A Report to the Carnegie Foundation for the Assessment of Teaching, Carnegie Found. For Assessment Teaching Bull. 5, 19, 21 $23(1910)$.

8. Id. at 19. 
could be assessed. ${ }^{9}$ Over the next decade, surveys, particularly of state systems, were done by the U.S. Bureau of Education, by private foundations, and by state legislative committees. ${ }^{10}$ This Progressive-Era development took place during a critical point in the consolidation of different educational forms into a relatively homogenous model topped by clearly defined administrative functions; by 1913 higher education accreditation had spread nation wide. "With the establishment of accreditation boards and with productivity and efficiency as the philosophical basis for standards which could include land grant schools; agriculture and mechanical schools; and research universities and colleges; higher education first came to be charged "with the responsibility to train people for jobs, rather than for character, citizenship, or leadership." 12

A few years into the Reagan administration, state legislatures began passing legislation calling for higher education accountability. In 1985, the Colorado State Legislature passed House Bill 1187 establishing a higher education accountability program requiring institutions to assess undergraduate "knowledge, capacities, and skills" and to report results to the Colorado Commission on Higher Education beginning with the 1989 to 1990 academic year. ${ }^{13}$ In 1986, the Illinois Board of Higher Education asked for review of undergraduate education in public colleges and universities, which included assessment. ${ }^{14}$ Perhaps the oldest assessment mandate is in the Wisconsin system, which "has required some form of student outcomes assessment from all [University of Wisconsin] institutions since 1900 in order to demonstrate to the Board of Regents and the legislature that the university is being responsive to the public demand for greater accountability." ${ }^{15}$ Assessment may be mandated by state legislatures, as at Washington State University. ${ }^{16}$ It may

9. BARRow, supra note 1 , at 70 .

10. Id. at $95-123$.

11. See Veysey, supra note 1, at 313.

12. Barrow, supra note 1 , at 119.

13. See The Regents of the University of Colo., Outcomes Assessment: The History of CUBoulder's Outcomes Assessment Program (2001), at http://www.colorado.edu/pba/outcomes/ovview/ oahist.htm (last visited Aug. 21, 2004).

14. See Douglas Eder, University Committee on Assessment, Southern Ill. University at Edwardsville, University Assessment Plan (Feb. 23, 1989), at http://www.siue.edu/ - deder/assess/ plan.html (last visited Aug. 21, 2004).

15. Board of Regents of the University of Wis. System, Outcomes Assessment: Manual 1, at http:// www.wisc.edu/provost/assess/manual/manuall.html (last visited Aug. 21, 2004). Wisconsin has a long history in assessment. $C f$. Cooke, supra note 7.

16. See Wash. State University, Accountability Plan, at http:/www.wsu.edu/ - aaa/accountabilityplan. htm (last visited Jan. 28, 2004). 
also be required by its accreditation body, as is the case with the University of Illinois ${ }^{17}$ and Montana State University. ${ }^{18}$ Some accrediting agencies have made these outright requirements such as the North Central Association of Colleges and Schools, the accrediting agency for the University of Wisconsin. ${ }^{19}$

In 1995, Colorado Governor Roy Romer compared the diffuseness of college education to the specific needs of employers, and the time and expense of college to the much briefer time and employer-assumed expense of job training. ${ }^{20}$ One assessment expert paraphrased Governor Romer's concerns as follows: "What good is it for a college or university student to learn how to write the five-page academic theme when companies complain that baccalaureate graduates can't master the concise one-page business memo or exhibit simple business etiquette in dress, speech, and deportment?"21 Governor Romer himself stated:

I am really interested in working over a period of time with university leaders and with other governors to see if we can get at this issue: "What is the product of your institutions?" We've got to figure out what that product is that we expect, and then we have got to figure out how to measure it accurately. We need to figure out how to compare that information across institutions in a way that is meaningful to consumers. It's not as simple as comparing cars. But I think we can do a better job of communicating with people what the institutions are all about. ${ }^{22}$

Similar calls for educational assessment moved to the federal level as Representative John Boehner (R-Oh.), Chairman of the Committee on Education and

17. See University of Ill. at Urbana-Champaign, Program Evaluation and Assessment, at http:// www.dmi.uiuc.edu/progeval/progeval.htm (last visited Jan. 28, 2005).

18. See Mont. State University-Bozeman, Student Outcomes Assessment: Background (2002), at http://www.montana.edu/aircj/assess/background/ (last visited Aug. 26, 2004).

19. See Board of Regents of the University of Wis. System, supra note 15.

20. See Douglas Eder, Southern Ill. University at Edwardsville: Why Do Assessment?, at http:// www.siue.edu/ -deder/assess/why.html (last visited Jan. 28, 2005) (paraphrasing a speech given by Colorado Governor Roy Romer).

21. Id.

22. Id. (quoting a speech given by Colorado Governor Roy Romer). 
the Workforce, addressed witnesses at the hearing for the reauthorization of the Higher Education Act in May 2003. ${ }^{23}$ In his opening statement, The State of American Higher Education: What Are Students, Parents and Taxpayers Getting for Their Money?, Boehner listed the "four guiding tenets" of reauthorization: "accessibility, accountability, affordability, and quality." He elaborates:

Accountability is the hub of the higher education wheel. Previously mentioned tenets, accessibility, affordability, and quality are the spokes that keep the wheel in motion. Before we move the reauthorization legislative vehicles through the House, I want to explore how postsecondary institutions are accountable to students, parents, and taxpayers. I am aware that institutions report volumes of data to the federal government and others, but ... [d]oes that reporting provide valuable accountability? Moreover is the data reported the right data ... [and] is it enough data ...?

And I have learned that in some States, public colleges and universities require their students to take basic skills assessments before, during, and after their degree program. Assessment results provide the higher education system, the State and policymakers, students and families, with tangible results about the quality of the education provided. These results help families make important decisions about their investment in postsecondary education. In many instances these assessment results also help States make performance-based funding decisions about the public institutions. And I am interested in hearing about the opinions of the witnesses here today on the value of this type of assessment. ${ }^{24}$

Boehner's concern is with tuition increases that outstrip the Consumer Price Index. ${ }^{25}$ Speaking on behalf of "stakeholders and investors" in higher education,

23. See The State of American Higher Education: What Are Parents, Students, and Taxpayers Getting for their Money?: Hearing Before the House Committee on Education and the Workforce, 108th Cong. 1-3 (2003) (statement of Rep. John Boehner, Comm. Chairman), available at http:// www.access.gpo.gov/congress/house/house06ch108.html (last visited Jan. 28, 2005) [hereinafter The State of American Higher Education].

24. Id. at 2.

25. Id. at 3 . 
that is, federal and state governments, students, parents, taxpayers, and employers, he asks how colleges and universities can "provide all of the stakeholders with an assurance that the investment made in postsecondary education will be returned to them in the form of a strong, viable, and educated workforce?" 26

Romer's and Boehner's arguments come across as incontrovertible common sense: those paying for higher education should get value for their money. The value of higher education lies in its outcomes, chief among which are employment opportunities; the only way to find out if people get what they pay for is to measure those elements of education that lead to employment opportunities. The common sense of these arguments appears to be chiefly about students and whoever pays their tuition, which may include the federal or state governments. Employers are but one party in the list of stakeholders. Looking beneath this common sense, we find that these arguments are not simply about the needs of specific employers or stakeholders; they are about reshaping the workforce through higher education to meet the levels and forms of productivity sought by increasingly globalized corporate interests.

\section{Education, Globalization, and the Shape of the Work force}

Joel Spring lays out the economic dynamics that he sees as having characterized the Reagan/Thatcher era to the present. ${ }^{27}$ In this neoliberal free market world, the role of government is to protect the workings of the free market. ${ }^{28}$ This means that government involvement in education (or any other social institution) is warranted only insofar as it promotes free market competition "as beneficially as possible." 29 Spring argues that such involvement may mean deploying educational policies in ways that shape students into the kinds of workers that the free market can use, or to put it even more strongly, in ways that "ensure favorable market conditions." 30 Spring cites the 1995 European Commission White Paper, "Teaching and Learning-Towards the Learning Society," which makes this perspective clear. ${ }^{31}$ Posited as the future of Europe, the learning society is one in which all workers must be in a state of constant

26. Id. at 3 .

27. Joel Spring, Education and the Rise of the Global Economy 120 (1998).

28. Id.

29. Id. at 123 (quoting F.A. HAyeK, The Road to Serfodom 21 (1994)).

30. See id. at $120-21$.

31. Id. at 102 . 
readiness to retool for changing labor market needs. ${ }^{32}$ This assigns major responsibility to "education systems-which means primarily the teachers-and all of those involved in training" and to workers themselves. "There is no single pattern for all to follow throughout their working lives. Everyone must be able to seize their opportunities. " 33 The job of the European Union (EU) is to provide systems of education that can both provide a broad base and allow for continual updating of skills. ${ }^{34}$ Toward this end, the White Paper recommends a system of skills accounting, including a "personal skills card," providing a record of recognized and validated skills. ${ }^{35}$ Such an accreditation system would facilitate labor interchange across EU countries; movement in that direction seems to be proceeding piecemeal in different fields. ${ }^{36}$ Similarly, the United Kingdom has developed a four-category Skills Audit. ${ }^{37}$ Spring also cites the Organisation for European Economic Co-operation and Development and the World Bank as agencies "responsible for spreading human capital analysis of education to developed and developing countries." 38

Given so widespread a set of influences on education and employment, it is not surprising that, as Spring notes, education discourses in the United States, the United Kingdom, and continental Europe are dominated by terms like "measurement, standards, accountability, human capital, human resources, social investment, and marketability." ${ }^{39}$ Spring sees such discourse as a contemporary and globalized manifestation of educational processes that, in the United States at least, have been going on for at least a century and a quarter, starting with "the introduction of vocational guidance, vocational education, standardized testing, ability grouping, and tracking in high school" as part of education

32. Id. at 102-104.

33. Teaching and Learning - Towards the Learning Society: White Paper from the Commission of the European Communities, $\operatorname{COM}(95) 590$ final at 2-3 [hereinafter Towards the Learning Society].

34. See id. at 2-4.

35. Id. at 19.

36. See, e.g., Daniel Souery \& Julien Mendlewicz, European Accreditation Committee, ENCP Matters, at http://www.encp.nl/Matters/number2/EACinCNS.htm (last visited Aug. 20, 2004) (discussing the efforts of the European Accreditation Committee in continuing medical education in specific areas such as the central nervous system to establish common methodologies and educational standards).

37. SPRING, supra note 27 , at 145.

38. Id. at 159.

39. Id. at $150-51$. 
"for specialized work roles." ${ }^{40}$ This perception of education was reinforced by the Cold War and competition with the Union of Soviet Socialist Republics. A 1947 report by the President's Commission on Higher Education, Higher Education for American Democracy, indicates that an intensified emphasis on training for skills emerged early in the Cold War. ${ }^{41}$ Regarding this Commission, Harold Wechsler notes:

The Commission cited rapidly changing conditions in the American economy as well as the contemporary political climate to justify its stand. The major economic change, resulting from the rapid advancement of American technology, was a shift in the economy's occupational center from the major producing industries to the distributive and service trades. One result of this, the Commission said, "is a new and rapidly growing need for trained semiprofessional workers in these distributive and service occupations." ${ }^{42}$ Increased technological complexity would call forth a variety of talents, including "social sensitivity and versatility, artistic ability, motor skill and dexterity, and mechanical aptitude and ingenuity. ${ }^{43}$

Preserving U.S. democracy required " a combination of social understanding and technical competence" "with the latter being "intensive, accurate, and comprehensive enough to give the student command of marketable abilities." ${ }^{\prime 4}$ Finally, the student citizen's general education should include "acquisition of skills involved in critical and constructive thinking." "45 This emphasis on students being readied for democracy and the post-war labor market segued into education for democracy and national security in the post-Sputnik era with the 1958 passage of the National Defense Education Act (NDEA). ${ }^{46}$ Skipping ahead several decades,

40. Id. at 151 .

41. See Harold S. Wechsler, The Qualified Student: A History of Selective College Admissions in America 253 (1977) (quoting President's Commission on Higher Education, Higher Education for American Democracy: Volume I, Establishing the Goals 68 (1947)).

42. Id. (quoting President's Commission on Higher Education, supra note 41, at 68).

43. Id. (quoting President's Commission on Higher Education, supra note 41, at 32).

44. Id. (quoting President's Commission on Higher Education, supra note 41, at 69).

45. Id. at 254 .

46. Joel Spring, The Sorting Machine: National Educational Policy Since 1945, at 96-113 (1976). 
we find "education-for-national-security" segueing into "education-for-globalcompetition." Colleges and universities now routinely describe their higher education offerings in terms of "skills-for-the-new-world-order," discourses which are congruent with EU and U.K. discourses on education and skills accounting. ${ }^{47}$ One especially well-known and frequently cited example was published by a liberal arts college president addressing consumer and stakeholder desiderata in liberal arts education. ${ }^{48}$ In addition to cognitive skills ("problem-solving, critical thinking, and "learning to learn"') and presentational skills ("the ability to write and speak clearly, persuasively, and coherently about oneself, ideas, and data"), the author describes social skills as "the ability to work cooperatively with others in a variety of settings," "[i]ntercultural understanding, the ability to work with people regardless of race, gender, age," "[i]nternational experience" and "foreign language facility." 49

\section{The Rhetoric of Skills and Skills Accounting}

The United States, the United Kingdom, and the European Union share a rhetoric of skills accounting that presupposes skills as things consisting of assessable parts or operations, such that common systems of measurement can be established across skill sets. ${ }^{50}$ What actually constitutes skills is often not sharply definable or consistent. This is not surprising, since skills consist of practices or forms of knowledge that can cover a wide range of possibilities. For example, the EU White Paper uses skill in reference to forms of knowledge (languages, maths, management, and accounting) or modes of practice ("sense of order, certain areas of decision-making"). ${ }^{51}$ Similarly, in her study of Britain's contemporary communication culture, Deborah Cameron notes that the highly scripted and monitored verbal routines that constitute call center labor are routinely labeled communication skills, but so too is a highly generic, much less scripted notion of "effective communication." 52 The former might fairly be typified as

47. Bonnie Urciuoli, Excellence, Leadership, Skills, Diversity: Marketing Liberal Arts Education, 23 Language \& Сомм. 385 (2003) (discussing college and university promotional discourse).

48. Richard H. Hersh, Intentions and Perceptions: A National Survey of Public Attitudes Toward Liberal Arts Education, Change, Mar./Apr. 1997, at 16-23.

49. Id. at 22 .

50. SPRING, supra note 46, at 96-113.

51. Towards the Learning Society, supra note 33, at 19.

52. Deborah Cameron, Good to Talk: Living and Working in a Communication Culture $17-18(2000)$. 
assembly line work while the latter might be typified as a management style. From that perspective, they are quite different kinds of practices.

As noted earlier, Joel Spring finds that globalized educational discourses tend to be dominated by an accounting rhetoric apparent in terms such as "measurement, standards, accountability, [and] human capital." ${ }^{\text {"3 } 3}$ To that list we might add skills and assessment. I have analyzed such terms of reference as strategically deployable shifters, or SDSs. ${ }^{54} \mathrm{An}$ SDS is a term whose semantic content is typically treated as definite, self-evident, almost tangible, although that content is largely abstract and often underspecified. ${ }^{55}$ The sense of self-evident definiteness derives from its contexts of use and from its user's alignment with particular social perspectives. ${ }^{56}$ SDSs can thus shift meaning across contexts, depending on alignments, to the extent that people using them in quite different contexts can characterize themselves as talking about "the same thing" while actually engaging in quite different acts of reference. Common examples in public discourse include words like values, democracy, diversity - all terms that take on quite different meanings by different users in different contexts but the use of which across contexts tends to promote a sense of "everyone really talking about the same thing." Skills and assessment also function in this way. They appear to have quite definite and tangible referents, a definiteness which derives cumulatively from the ways in which they have come to be used, by whom, and to what ends. In this section, I will examine the ways in which skills and assessment, as SDSs, are used by U.S. academic administrators to indicate their fit-not just in terms of compliance but as ideological alignment - with the concerns of the dominant agents of the globalized labor market and legislative mandates. The underspecification will become evident as I discuss acts of reference involving these terms.

The adjective "skilled" emerged in the eighteenth century denoting technical expertise associated with labor (i.e., skilled labor, skilled laborers).$^{58} \mathrm{Nine}$ teenth century skilled laborers had a degree of control over what they did and when and how they did it, until the "de-skilling" of the era typified as Taylorist

53. SPRING, supra note 27 , at 149-50.

54. Urciuoli, supra note 47. "Strategically deployable" refers to the ways in which such terms can be used to establish social alignments; "shifter" refers to the fact that semantic interpretations depend on that alignment. Id.

55. Id.

56. Id.

57. Id.

58. Oxford English Dictionary 2847 (Compact ed. 1971). 
(i.e., the era of scientific management beginning around 1890). ${ }^{59}$ The laborer's job was dissected, analyzed, and reassembled by labor engineers using, for example, time and motion studies to reconstruct the job more efficiently. ${ }^{60}$ The same Taylorist principle has been applied to any number of jobs since then, including the forms of call center work defined, as noted by Cameron, as "skills." Canonically, in contemporary discourse, "skill" has emerged as a noun denoting some form of knowledge or practice possessed by a worker that fits the worker to a job. ${ }^{62}$ Thus, skills are practices or knowledge that contribute to an organization's productivity. How Taylorized that skill might be depends on the job. Call center jobs are tightly structured around the worker's time allotments for specific tasks. ${ }^{63}$ The interactively standardized, scripted nature of the job is determined by cost accounting, which is similar to the process of assembly line work. ${ }^{64}$ By contrast, the kind of communication skill that a "team facilitator" might exhibit (in the "leaderless management" of the "new workplace") is not the ability to perform a script but the capacity to move a group of fellow employees (one's "team") to accomplish a task with minimal false starts or disagreements. How well one performs these "communication" jobs may depend on a number of contributing factors quite outside the worker's control. But the skill model makes it possible to abstract an idealized model of the job from the realpolitik of work, break it into pieces, and evaluate each piece separately. Thus, we see the emergence of skill as an SDS: an abstraction used as if it were highly concrete, with different referents in different contexts, and used in ways indicating an alignment with a particular labor-management ethos. Furthermore, skills, and the notion of skills assessment, have become fetishized in the Marxist sense: the process of reification subsumes into them, as if inherent, capacities that exist as a result of the social nexus in which they operate. They seem to have a sort of operational magic.

The language of skills accounting works in similar but not identical ways in the United States, the United Kingdom, and the European Union. In Britain

59. See generally Harry Braverman, Labor and Monopoly Capital: The Degradation of Work in the Twentieth Century 112-37 (1974).

60. See David Noble, America by Design: Science, Technology and the Rise of Corporate Capitalism 257-80 (1977).

61. See Cameron, supra note 52, at 95.

62. I should note that not every usage of skill is about jobs, but this usage does dominate.

63. See Cameron, supra note 52, at 95.

64. Id. 
and the European Union, skills assessment is part of an audit culture, a government mandated extension of accountability procedures into all areas of public life, including education. ${ }^{65} \mathrm{Chris}$ Shore and Susan Wright note that "[a]udit thus becomes a political technology of the self: a means through which individuals actively and freely regulate their own conduct and thereby contribute to the government's model of social order." ${ }^{\circ 6}$ In the United States, accountability procedures are more diffused and less regulated. The hand of government policy is, not surprisingly, less directly manifest given the size of the U.S. economy and the proportion of it that is private industry. Much of the accountability ordering in U.S. business is done in-house or carried out by private consultants. Where the direct hand of government oversight is quite firmly felt is in the education sector, particularly public education.

Earlier in this essay, I sketched some of the language used by Governor Romer and Representative Boehner to justify the strengthening of that oversight. Romer speaks of education as a product, treating product as an SDS as if it is a definite, measurable object, as if an academic product is "the same as" an industrial product, and in a way that aligns his interests with corporate interests, framing both as both self-evident and right, which amounts to a moral statement. Boehner develops the "product" theme at length with his "wheel" trope of higher education (accountability as the hub, accessibility, affordability, and quality as the spokes). ${ }^{67}$ Assessment is a key SDS here; it aligns his interests with that of the "stakeholders." It presupposes a tangible object whose semantic content becomes what works best for his interests. The idea that education could have significant outcomes that are not readily subject to assessment lies outside this discussion.

It is helpful to examine the forms of discourse in which educators take up such concerns. Southern Illinois University at Edwardsville (SIUE) has an assessment program that has been cited for "Best Practice" and "Academic Excellence." ${ }^{68}$ It defines assessment as "our source of in-process feedback." 69 "As

65. Cris Shore \& Susan Wright, Coercive Accountability:The Rise of Audit Culture in Higher Education, in Audit Cultures: Anthropological Studies in Accountability, Ethics and the Academy 61-63 (Marilyn Strathern ed., 2000).

66. Id. at 62 .

67. The State of American Higher Education, supra note 23.

68. Southern Ill. University, Undergraduate Assessment \&. Program Review, at http:// www.siue.edu/ -deder/assess/ (last updated Jan. 12, 2005).

69. Eder, supra note 20. 
opposed to grades (see Primary Trait Analysis), assessment decomposes the curriculum (or an assignment, class, or course) into component parts and makes those parts visible. Second, assessment satisfies the demands for accountability by external agencies." ${ }^{70}$ The SIUE assessment website provides as examples of parts the different sections of a student's scientific paper-introduction, materials and methods, results - each of which can be recognized as central to the discipline and framed in a rubric describing levels of achievement. ${ }^{71}$ Primary Trait Analysis is thusly explained:

When professors talk grades, they can have animated conversations about students, but they can't talk meaningfully about comparative strengths and weaknesses of the curriculum. When professors talk assessment through Primary Trait Analysis (PTA), they can decompose the curriculum (or a course, a class, or an assignment) into parts and have a meaningful conversation about teaching and learning. This is because Primary Trait Analysis does not yield a single, holistic grade. Instead, it reveals parts. Two examples follow in parallel, one approximating what professors do when recording grades, another outlining what professors could do with the same information when performing PTA. ${ }^{72}$

The first example, typified as grading, describes an impressionistic process whereby an assignment is "unconsciously" compared to an ideal. The second employs a rubric whereby specific elements of an assignment or project are "consciously" described and assigned a number score, providing a multipart analysis of outcome. This example posits the existence of a technique, which, if followed, guarantees a measurable result. Its use by all department members can, in theory, establish procedural transparency and standardization among department faculty and answer the question, "Is the student learning what I mean to be teaching?"

70. Eder, supra note 14.

71. Douglas Eder, Southern Ill. University, Primary Trait Analysis: Grades vs. AssessmentScience Example, at http://www.siue.edu/ deder/assess/cats/ptaex.html (last visited on Jan. 20, 2005).

72. Douglas Eder, Southern Ill. University, Primary Trait Analysis, at http:/www.siue.edu/ $\sim$ deder/assess/cats/pta.html (last visited Jan. 20, 2005). 
Assessment occurs here as the same sort of strategically deployable shifter as in Boehner's statements. Assessment is given a definite referent, distinct from mere grading. ${ }^{73}$ Yet, the PTA procedure described here looks much like the multipart grading rubric that my colleagues and I have used over the years to assign grades, especially in team-taught courses or in situations where we have had to grade jointly, as on senior projects. Nor is there any guarantee that the numberscoring procedure involved in PTA is any more objective than what this author typifies as grading. Moreover, the reification rests on belief in the technique per se. In doing so, it assumes the good faith and transparency of the teaching act in much the same way that Deborah Cameron describes a person's belief in communication skills, assuming the good faith and transparency of an idealized and apolitical communication act. ${ }^{74}$ The assumption is that the technique itself has a sort of purity, independent of users' intentions or of institutional or social relations of power and authority. This use of assessment exemplifies U.S. style audit culture in that it "satisfies the demands for accountability." 75 The arbitrariness of the distinction between grading and assessment is at least as much about the author's self-alignment as it is about the usefulness of the technique itself.

In the website for the University of Wisconsin's accreditation program, we see again a use of language presupposing assessment as a self-evident thing, and as a mode of social alignment. The site lists "ten characteristics of an effective program to assess student academic achievement," including:

Successful assessment flows from the institution's mission and educational purposes[;]... emerges from a conceptual framework[;] ... is marked by faculty ownership and responsibility[;] ...has institution-wide support;... relies on multiple measures[;] ... provides feedback to students and the institution[;] ... is cost-effective[;] ... does not restrict or inhibit goals of access, equity, and diversity established by the institution[;] ... leads to improvement[;] ... includes a process for evaluating the assessment program. ${ }^{76}$

73. Id.

74. See Cameron, supra note 52, at 164.

75. Eder, supra note 20.

76. Board of Regents of the University of Wis. System, supra note 15. 
The emphasis here is on the systemic nature of assessment, starting with a clear institutional mission, playing out through multiple measures, and leading to improvement culminating in a list of the benefits that assessment ideally achieves. The instruments and methods through which this is done include such "[d]irect [i]ndicators of [1]earning" as "[c]apstone [c]ourse [e]valuation," "[c]ourse-[e]mbedded [a]ssessment," "[t]ests and [e]xaminations," "[p]ortfolio [e]valuation," "[p]re-test/[p]ost-test [e]valuation," "[r]hesis [e]valuation," "[v]ideotape and [a]udiotape [e]valuation of [p]erformance," and "[i]ndirect [i]ndicators" such as "[e]xternal [r]eviewers," student surveys and exit interviews, alumni surveys, employer surveys, and "[c]urriculum and [s]yllabus [a]nalysis." 77 Many, perhaps all, of these devices provide useful information, but the question is, "is all that information really commensurate?" Do all these devices fit together into a coherent whole? Those not familiar with the various practices, innovations, and technological trends of college teaching might see in this list of techniques more coherence and forethought than might be evident to those who have been teaching for some years. The coherence lies at least as much in the mode of presentation as in the total assembly; this list is a sort of mosaic of good intentions and practices-at-hand tied to institutional mission statements. ${ }^{78}$ If the people speaking for the institution have a choice, they might say that education is a complex process without simple products or built-in commensurability, but can they say that to state legislators? ${ }^{79}$

SIUE is a state university whose graduate offerings are largely at the master's level. Wisconsin is a traditional state university system. Like other state institutions, they undertook assessment in response to mandates from state legislatures, their accreditation program, or both. By contrast, Hamilton College, a private, nationally ranked, liberal arts college, undertook self-assessment partly in response to suggestions from a major foundation from whom it was pursuing grants, and partly in its own quest for a distinct niche in its comparison

77. Board of Regents of the University of Wis. System, Outcomes Assessment: Manual 2, at http:// www.wisc.edu/provost/assess/manual/manual2.html (last visited Sept. 21, 2004).

78. See, e.g., University of Wis., Mission Statement, available at www.chancellor.wisc.edu/mission. html (last updated June 10, 1998).

79. A refreshing example of what a private college can say is provided by Carleton College, whose assessment project insists on the importance of suiting the assessment process to the nature of the school and the particular nature of what students learn in what departments. See Jacqulyn Lauer-Glebov, Getting Out of the Way: Assessment from the Peanut Gallery, Paper delivered at Higher Education Data Sharing Conference, Boise, Idaho (June 2004). 
group. ${ }^{80}$ This institution has had an on-campus consultant in a yearlong visiting position, doing assessment development among faculty through workshops and department consultations. The institution has also undertaken two grantsponsored studies with former and current students, as to their perceptions of specific curricular elements (writing, oral communication, and quantitative skills) and selected elements of student life. These studies have also examined several years worth of student writing. ${ }^{81}$

The five discrete skills most often named include oral and written communication, analytic, problem solving, and critical thinking. The question is not whether teachers should pay attention to these qualities of student work. Teachers do routinely evaluate these qualities as part of students' course work, along with the course work that the student submits, as in a test, essay, research paper, or some other course-related project. The question is whether these are discrete, parallel, and comparable entities which can be assessed the same way across the institution. One way to find out is to ask how students themselves perceive these as skills.

In a recent study at Hamilton College, researcher Shauna Sweet examined surveys of graduating seniors in 2003 and 2004 and specifically compared responses to questions that asked how well students thought their undergraduate experience had enhanced a number of capacities, including the capacity to write effectively, communicate well orally, and use quantitative tools. ${ }^{82}$ She found that students had a clear sense that "writing effectively" is a defined object with a clear explanatory language. Across disciplines, students agreed on what it is, what its techniques are, and how their writing had improved. Students had some perception of "communicating orally" as a defined object but without a clear explanatory language. Across disciplines, they more or less agreed on what oral communication was (i.e., a form of speaking), but were unsure on how to do it and tended to think of improvement in terms of "just speaking" more. Students expressed no clear sense of "use of quantitative tools" as a defined object nor did they have an explanatory language for it. Across disciplines, in fact, they actually disagreed on what counts as quantitative. In addition, students tended

80. This occurred in a period when the state of New York sought greater accountability and teaching standards.

81. Hamilton College, The Hamilton College Strategic Plan 13-14 (2002).

82. Shauna J. Sweet, Survey: Valuing Skills Across the Curriculum. This survey was presented at the June conference of the Higher Education Data Sharing conference in Boise, Idaho (June 2004). The quotes in the following paragraphs are from the questionnaires used in the survey. 
to regard the capacity to write well as something that anyone can learn, especially with frequent practice, and that everyone needs to know. They tended to regard oral communication as something that most people can learn through repeated applications of technique but also believed some people are "naturally" better at it than others and that not everyone needs it. They tended to regard the use of quantitative tools as the most natural and the least readily learned through applied technique ("either you know it or you don't"). Majors in quantitative disciplines tended to regard such knowledge as important for everyone, while students in non-quantitative disciplines considered such knowledge unnecessary beyond a basic level.

Students were not asked "do you have these skills," but rather whether certain "abilities" or "capacities" that "may be developed in a bachelor's degree program" were "enhanced by their undergraduate experience," and whether they were enhanced "not at all," "a little," "moderately," or "greatly." 83 Although the word introducing each capacity was a verb: "write effectively," "communicate well orally," and "use quantitative tools," there seemed no doubt among the project personnel or the students that these constituted skills. The key linguistic point here is that even if these capacities are described as verbs, the verbs and their objects or modifiers operate as parts of noun phrases: "the capacity to [do X]." The presupposition is that these capacities are thing-like (they can be developed or enhanced) with a substance-like quality (they come in increments of more or less). As noted above, they are routinely referred to as skills, as when the college's literature describes its emphasis on "writing, speaking and critical thinking skills" or "analytic skills." 84 In higher education, as in corporate usage, "skill" has become an unproblematic hyponym for a whole range of knowledge, practices, and capacities.

One might argue that student perceptions are not well formed, that youth and inexperience means they do not fully understand what each skill set means, and that this accounts for their uneven perceptions; but this is a school that centrally defines itself in terms of writing. It has a high-profile writing center and intensive writing program worked into its graduation requirements and spread over the curriculum. ${ }^{85}$ The school is proud of its many graduates who have gone

83. Id.

84. See Hamilton College, About Us, at www.hamilton.edu (last visited Jan. 19, 2005). These terms may be found in various configurations throughout the college's website.

85. Hamilton College, Nesbitt-Johnston Writing Center, at www.hamilton.edu/academics/ resource/wc/(last visited Jan. 19, 2005). 
on to make names for themselves as novelists and playwrights. It is not surprising that so many students identify themselves as practitioners of a high status and heavily promoted activity that they already had some (often a great deal of) familiarity with before they got to the college. The college has also always identified itself with rhetoric; it once had a public speaking requirement and has recently developed an oral communication program, which its literature promotes. ${ }^{86}$ Yet, writing has been, at this school at least, powerfully associated with humanities in ways that oral communication has not, though students are well aware of the utility of the latter. Quantitative practices seem even further from their horizons, with little presence or status for most students. These differences in what is available to students' perceptions do affect what students think they are learning, particularly when they are asked about capacities that are hard to imagine apart from a particular subject matter.

Across these three schools, it appears that the institutional authorities writing about assessment are primarily concerned with asserting regularity and systematicity, mapping order onto beliefs and practices that are not inherently ordered as regular, discrete "things" with unambiguous outcomes and clear benefits. What strikes one most powerfully in this language is its assertion of objectivity, regularity, and beneficial process, linked to attitudes of alignment and compliance with authorities above the school.

\section{Why Now? The Renewed Call for Educational Assessment}

It has never been quite clear who "produces" the higher education "product"; do faculty "own" their own means of production or does the institution, which would mean the faculty is a form of supervised labor? Non-academics rarely see, or grasp the nature of, the arrangements worked out within institutions where, generally, "production" is most immediately organized by faculty and departments within institutional parameters. Under those circumstances, it is not surprising that faculty, who are most readily conceptualized as labor, become lightning rods for outsiders, especially for corporate and legislative critics, who see educational institutions as inappropriately organized and inexcusably vague. Conservative political administrations tend to be particularly suspicious of unruly educators; this is especially true of the current Bush administration

86. Hamilton College, Oral Communication at Hamilton, at www.hamilton.edu/academics/ department.html? dept =oral\%20communication (last visited Jan. 20, 2005). 
which has committed itself to a heavily scientized (Taylorist, even) rhetoric of teacher training and supervision. ${ }^{87}$ In addition, recent years have seen escalating college costs, and new exigencies of a globalized economy. ${ }^{88}$

David Kirp provides a detailed outline of the ways in which colleges and universities have found themselves caught up in expensive niche-market wars ${ }^{89}$ A 2001 survey found that the student market defines college in terms of "getting career training, getting a better job and making more money"; what matters most is not the quality of a college's education but the prestige of its name. ${ }^{90}$ There was always some sense of students as customers; now there is no "some sense" about it. Colleges and universities have had to dive full tilt into expensive advertising and service provision to draw those customers. ${ }^{91}$ Schools have found themselves making major investments in star faculty recruitment to buttress institutional reputations. ${ }^{92}$ Schools pay fees to marketing consultants, and they expand admissions and marketing divisions to generate new ideas to draw higher-end customers (students). ${ }^{93}$ Salaries do rise, and faculty salaries count in the U.S. News rankings. ${ }^{94}$ Taken individually, any of these may seem expendable, or worse, silly luxuries, but the "facilities race" in which schools find themselves must seem unavoidable to its participants. Therefore, costs keep rising. For state university administrators who must stay viable in that race, being taken to task by legislators like Boehner must be excruciating.

Furthermore, a greater proportion than ever of high school graduates enters some form of higher education. Although admission to the highest ranked institurions has become highly competitive, there are many higher education institutions still available. ${ }^{96}$ Moreover, the U.S. workforce has become increasingly

87. See, e.g., Kathleen Hall, Science, Globalization and Educational Governance: The Political Rationalities of the New Managerialism, Ind. J. Global Legal Stud., Winter 2005, at 153.

88. See David L. Kirp, Shakespeare, Einstein, and the Bottom Line: The Marketing of Higher Education 2-3 (2003).

89. See id.; see also Derek Bok, Universities in the Marketplace: The Commercialization of Higher Education (2003).

90. KIRP, supra note 88, at 12.

91. Id. at 23-24 (reporting that electronic technology does not come cheap, dining halls have seriously upscaled college cuisine, and installations of pricey recreational facilities increase costs).

92. In particular, schools strive to make that all-important top $25 \%$ of the U.S. News and World Report America's Best Colleges rankings.

93. See generally $\mathrm{K}_{\mathrm{IRP}}$, supra note 88 , at 11-32 (discussing the marketing of higher education).

94. E.g., Undergraduate Ranking Criteria and Weights, at www.usnews.com/usnews/edu/ college/rankings/about/weight_brief.php (last visited Jan. 21, 2005).

95. Kirp, supra note 88, at 24 (quoting an analyst from Standard and Poor's).

96. Gould, supra note 2, at 29-30. 
demographically diverse, in a corporate climate that treats diversity as a sort of skill (as evidenced in the "valuing diversity" rhetoric of corporate Human Relations departments). ${ }^{97}$ A bove all, this is a work force that is supposed to be crafted, by its training institutions, to fit globalized needs. Therefore, much of the rhetoric is driven by a sense of competition, of the U.S. workforce being part of a global race. This is reinforced by the logic of outsourcing, of reassigning U.S. jobs to non-U.S. workers with the same or better skills and a lower price tag. It becomes the worker's task to beat those odds.

Let me summarize the common sense of educational outcomes assessment. Higher education operates in a neoliberal market atmosphere in which higher education is conceptualized as a skill provider, skills being pieces of a job. The nature and importance of a job skill is defined by the specific outcome of that job, and it is against that outcome that a skill can, in theory, be assessed. The product of the educational process should, therefore, be such usable skills, and the efficacy of education can be decided by assessing the product. Because education is getting increasingly expensive, those skills had better be worth it. Because the laborers providing those skills are the teachers, teachers and what teachers do must be assessed. And since most higher education institutions use some public funding, they have to conform to public demands, enforced by legislative action heavily subject to political concerns.

There are three things wrong with this picture. First, what, specifically, are these things called "skills"? Gould said of Hersh's skills survey ${ }^{98}$ that Hersh perceives liberal arts as "little more than an argument for the socially therapeutic value of the arts and sciences mysteriously added to some practical skills courses, a formula that has been in place in many urban universities for years already." ${ }^{.99}$ I have already noted the conflicting principles of skills classification outlined by Sweet. I also note that the SIUE website compares the five-page academic theme with the one-page business memo, two quite different writing genres. So how is writing a "skill" in the abstract? How is critical thinking, which is inextricably connected to specific subject matters, abstractly assessable? Second, the rhetoric creates a false impression of what the costs of education are really about. Kirp, in addition to outlining the market factors underlying the growth of college costs generally, notes

97. See, e.g., Marilyn Loden, Implementing Diversity (1996). See also Urciuoli, supra note 47, at 398 ("Diversity has for some years been the preferred term in corporate discourse, where it is a property of individuals, not groups....").

98. See Hersh, supra note 48.

99. Gould, supra note 2, at 16. 
that state funding for their higher education systems grows increasingly smaller. ${ }^{100}$ Third, the schools being asked to do assessment do so in ways that accept the terms of the neoliberal rhetoric and that are rather restricted to their existing resources; outside funding specifically for assessment is not a widespread option.

Skills rhetoric is ideologically framed by corporate and conservative political voices, within and outside the United States, that fetishize market logic not only as natural cause and effect, but also as a moral imperative. I analyze the SDSs saturating this rhetoric because they indicate the formation of a "cultural common sense" along alignments of political and corporate authority and influence. This provides a way to track the concatenation of social values driving calls for legislation. Legislators can thus reinforce the "common sense" of schools "doing their job" of modeling students as workers, with teachers the primary target for that responsibility. In the United States, "common sense" organizations and institutions are routinely treated as stand alones, unconnected to other social factors, and free of any history. Organizations are imagined to have clear, specifiable outcomes. This may be relatively true of private sector business organizations but those are a specific kind of organization. There is far more ambiguity as to what non-commercial institutions are "for"; what are churches "for"?

\section{Conclusion}

People who pay for college education, sometimes including the students themselves, do have a right to know why college education costs what it does, and what their kids are learning. And there are procedures that provide useful feedback. But the ideological thrust of the assessment discourse, as a whole, is about much more than providing useful feedback. It operates on the assumption that the corporate model can and should be privileged for education. Why? Why the idea that outcomes can be conceptualized as product? If the privileged language of skills assessment is as slippery as it is, should that not indicate that this is not the most useful way to think about education? If this hegemonic desire to map a protean grid of commensurability and political compliance onto the complex process of education is, as I have argued, mostly a form of moralism, then this call for assessment may not be primarily about improving education. It may be a declaration, enshrined in legislative mandate and reinforced by the new globalized common sense, of who belongs where in the new world order.

100. See Kirp, supra note 88 , at 132 (noting that $6.9 \%$ of state revenue now goes to state college and university systems, which provides only a fraction of most state school budgets). 